\title{
The Role of Financial Management Accountability in Enhancing Organizational Performance in Indonesia
}

\author{
Nusa MUKTIADJI ${ }^{1}$, Sri MULYANI ${ }^{2}$, Moermahadi Soerja DJANEGARA ${ }^{3}$, Bambang PAMUNGKAS ${ }^{4}$
}

Received: September 10, 2020 Revised: November 08, 2020 Accepted: November 16, 2020

\begin{abstract}
The study aims to investigate the implementation of the internal quality assurance system (IQAS) on HEIs performance, mediated by financial management accountability. The commitment from foundation leadership on financial management accountability and their implications for HEIs' performance is also carefully examined. This study employs samples of 108 respondents from the leadership of private HEIs under Region IV Service Institutions. The purposive sampling, as a part of non-probability sampling was chosen as the sampling technique. Statistical data analysis conducted by use the structural equation model to test the hypothesis. The results reveal that the implementation of IQAS does not influence the financial management accountability, but it has an essential role on HEIs' performance. Moreover, foundation leadership's commitment has a significant positive effect on financial management accountability and HEIs' performance. Financial management accountability also has a significant positive effect on HEIs' performance. Financial management becomes important because the entire activities of HEIs should end with financial reporting. Therefore, financial and non-financial aspects are two interrelated and complementary aspects in the accreditation process. The findings of this study suggest that that performance measurement is very crucial as a part of the efforts to meet the general accountability requirement for organizations, particularly in HEIs.
\end{abstract}

Keywords: Higher Education Institutions (HEIs), Internal Quality Assurance System, Accountability, Organizational Performance

JEL Classification Code: I23, L31, M10

\section{Introduction}

The national education system in Indonesia specifies three levels of education: primary education, secondary education, and higher education. Law No. 20 of 2003 stipulates that, as the highest level of education in the national education system, higher education consists of several programs: associate degree (diploma degree), bachelor, master's, specialized postgraduate program (i.e., professional and

${ }^{1}$ First Author and Corresponding Author. Doctoral Student, Universitas Padjadjaran, Indonesia [Postal Address: Ranggagading Street No.1 Bogor, West Java, 16123, Indonesia] Email: muktiadji@gmail.com ${ }^{2}$ Professor in Accounting Department, Universitas Padjadjaran, Indonesia. Email: s.mulyani2016@unpad.ac.id

${ }^{3}$ Professor in Accounting Department, Universitas Padjadjaran, Indonesia. Email: moermahadi2001@yahoo.com

${ }^{4}$ Professor in Accounting Department, Universitas Padjadjaran, Indonesia. Email: pamungkas62@yahoo.com

() Copyright: The Author(s)

This is an Open Access article distributed under the terms of the Creative Commons Attribution Non-Commercial License (https://creativecommons.org/licenses/by-nc/4.0/) which permits unrestricted non-commercial use, distribution, and reproduction in any medium, provided the original work is properly cited. specialist), and doctoral. Higher education institutions (HEIs) in Indonesia are run either by the government or private sectors.

The government's efforts to improve the quality of higher education in Indonesia have been implemented by improving higher education performance, one of which is by enacting the regulations on the implementation of quality assurance in higher education. For instance, article 52, paragraph 1 of Law No. 12 of 2012 on higher education states that quality assurance in higher education is a series of systemic activities to improve higher education quality in a planned and continuous manner. In other words, quality higher education is implemented and maintained in a systematic, well-planned, and continuous manner.

The quality of higher education in Indonesia, which reflects the performance levels achieved by HEIs, can be seen from the accreditation ratings from the National Accreditation Board for Higher Education (BAN-PT). Based on data from the Directorate General of Higher Education Service Institutions for Region IV West Java and Banten in 2018, there were 480 private HEIs in the region. However, only 145 (30.21\%) private HEIs were accredited (e.g., A, B and C), while the 
other 335 private HEIs (69.79\%) have not (www.lldikti4.or.id). This significant number of HEIs that had not been accredited indicates the performance level of private HEIs under Service Institutions for Region IV was still moderately low.

This study is conducted to examine the determinants that may influence the accountability of financial management and their implications for the performance of private HEIs in Indonesia. The two determining factors which are believed to be the ones that influence the financial management accountability of private HEIs. Those factors are implementing the internal quality assurance system (IQAS) and the foundation leadership's commitment to implement IQAS. Some previous research has been conducted on the factors that influence accountability and the influence of accountability on performance.

\section{Literature Review}

\subsection{Implementation of Internal Quality Assurance System (IQAS)}

The implementation of the internal quality assurance system (IQAS) in higher education institutions (HEIs) has been represented in higher education quality assurance. Article 52 paragraph 1 of Law No. 12 of 2012 defines higher education quality assurance as systemic activities to improve higher education quality, conducted in a planned and continuous manner. This indicates that the higher of organizational performance, the more excellence the quality of that HEI. IQAS is essentially an internal control process that constitutes the fundamental parts of good corporate governance. The existence of big data technologies nowadays can be utilized to help public administration in order to improve community's lives (Lee, 2020a) includes in educational sector. The main objectives of IQAS implementation are to identify and manage risks to a certain extent, enabling an organization to sustain its growth and continue performing its operations following the existing laws and regulations. A good internal control system is a way to create transparency and accountability and prevent fraud and financial irregularities in the allocation and disbursement of public funds at the local government level. A good internal control system also benefits an organization. It can prevent lousy financing, detect errors and financial irregularities in its operations, and help the organization work more effectively and harmoniously (Pathak, 2005; Wardiwiyono, 2012).

The internal control system has a significant role in ensuring financial management accountability. Bianchi (2010) suggests that internal control's role is to support system implementation, encouraging accountability in decision-making. Furthermore, other research results suggest that the increase of internal control monitoring and reports can improve the quality of financial reporting
(Altamuro \& Beatty, 2010; Indriasi \& Koeswayo, 2014; Kewo, 2017). The important role of financial management accountability also can be reflected in the essential role of green finance in achieving sustainable development goals (Lee, 2020b).

Aramide and Bashir (2015) explain that the internal control system is how an organization controls its operational activities effectively and efficiently. Moreover, this internal control system can also improve the reliability of the organization's financial accountability and ensure that it complies with the existing laws and regulations. Their findings show that the internal control system has a significant positive effect on local government councils' financial accountability in Nigeria. Based on these findings, Aramide and Bashir (2015) recommend that local government authorities create a more appropriate and effective internal control system that should be imposed on local governments to increase their financial accountability.

Aristanti (2015) researched the effects of the internal control components on several elementary schools' financial accountability. The results show that, partially, the control environment, the control activities, and monitoring had a significant effect on financial accountability. Furthermore, two components, i.e., risk assessments and information and communication, did not significantly affect financial accountability, but, simultaneously, the control environment, risk assessment, control activities, information and communication, and monitoring influenced financial accountability significantly.

The internal control system, including the internal audit, is intended to increase financial performance reliability, either directly or indirectly, by increasing the accountability of information providers in an organization (Jensen, 2000). Therefore, internal control can help the organization achieve broader objectives that cover organizational problems and protect the environment (Setiawan, Afiff, \& Heruwasto, 2020) related to lower revenues, disclosure of material weaknesses and frauds, and earnings management, which are independently assessed in terms of the quality of the managerial performance on undertaking the given responsibilities. Al-Thuneibat, Al-Rehaily, and Basodan (2015) believe that all dimensions of internal control (i.e., control environment, risk assessment, control activities, information and communication, and monitoring) have a positive relationship with all profitability measurements. In different contexts, Awdat (2015), Tuan and Nguyen, (2019), and Setiawan, Panduwangi, and Sumintono (2018) prove that there has been an increase in the implementation of internal controls in commercial banks, and this also reflects an improvement in their financial performances. In other words, internal control has been proven to have a positive effect on the performances of commercial banks. 
Based on the results of the aforementioned previous research, the proposed hypotheses of this present study are formulated as follows:

$\boldsymbol{H}_{1}:$ The implementation of IQAS has positive effects on the financial management accountability of HEIs.

$\boldsymbol{H}_{2}$ : The implementation of IQAS has positive effects on the performance of HEIs.

\subsection{Commitment from the Foundation Leadership}

Organizational commitment is a psychological condition that is characterized by the relationship between employees and the organization. This condition also affects the employees' decision to stay in the organization or not. This organizational commitment is identified in three types: affective commitment, continuant commitment, and normative commitment (Zurnali, 2010).

Fettry (2015) reports a positive influence between business ethics commitment and the quality of financial statements. Her research findings show that top management support, culture, ethical leadership, open communication channels, and ethics training are considered essential things that are necessary for improving the quality of financial reporting.

In the context of human resource development, Agyemang et al. (2017) suggest that field workers often crave to have a conversation about accountability. They can share their thoughts on developing accountability to a higher level of management. This enables them to fulfill their sense of responsibility. Agyemang et al. (2017), states that the levels of commitment from managers to their organizations have an indirect positive effect on accountability.

By studying the commitment of employees in Malaysia's public sectors, Johari, Alam, and Said (2018) argue that, in general, the data show that employees of public sectors commit various levels. For instance, the employee groups in the financial service scheme get a higher commitment value, while the employee groups in the accounting and audit service schemes obtain lower commitment values.

Luthans (2006) believes that organizational commitment is a strong desire to continue being a member of a particular organization, a willingness to strive hard in any tasks for achieving good results on behalf of the organization, and a definite belief in, and acceptance of, the organization's values and goals. In other words, this is the attitude that reflects employees' loyalty to their organization. It is an ongoing process by which members of the organization express their concern for the organization and its success and sustainable progress (Luthans, 2006).

Two research on the effects of organizational commitment on performance was carried out by Khan, Khan, and Khan
(2011) and Akhtar, Durrani, and Hassan (2015). Their results show that organizational commitment has a significant positive effect on employees' job satisfaction. Similarly, Atmojo (2012) argues that transformational leadership significantly affects job satisfaction and organizational commitment. Furthermore, job satisfaction is proven to influence employees' performance significantly, and organizational commitment significantly affects employees' performance.

Research on the CEO's role in improving its performance through organizational commitment was carried out by Chadwick, Super, and Kwon (2015). The result shows that CEO emphasis on strategic Human Resources Management (SHRM) significantly influences the company performance through a commitment-based HR system. In another research, Pradhan and Pradhan (2015) suggest that transformational leadership has a significant positive relationship to affective organizational commitment and contextual performance. Furthermore, affective organizational commitment also has a positive relationship with contextual performance. Thus, there is a positive and significant relationship among transformational leadership, affective organizational commitment, and contextual performance.

Based on the explanation, the proposed hypotheses in this study are formulated as follows:

$\boldsymbol{H}_{3}:$ The implementation of an accounting information system (AIS) has a positive effect on the financial management accountability of private HEIs.

$\boldsymbol{H}_{4}:$ The implementation of an accounting information system (AIS) has a positive effect on the performance of private HEIs

\subsection{Financial Management Accountability}

Accountability can be defined as the relationship between the parties who control and regulate an organization and the parties with formal authority over the controlling party. In this case, a responsible third party is also needed to explain, or practical reasoning for the entire activities carried out and the business outcome obtained as the results of task implementation and achieving a particular goal.

Hanushek and Raymond (2005) conduct relevant research regarding this issue. The results revealed the effect of accountability on educational institutions and public organizations' performance. Hanushek and Raymond (2005) report that their research's most significant results were acknowledging that accountability is essential for students in the United States. This positive effect of accountability is similarly gained from a series of alternative designs of basic achievement models in education. However, this effect only applies to states that attach consequences to performance. Other states that only give information via report cards without attaching consequences to performance do not 
have a much more significant impact than those without accountability at all. Interestingly, in digital era, there is a significant relationship between firm size and organizational actions on adopting social media for corporate reputation management (Becker \& Lee, 2019). This can be a robust argument that accountability in educational institution is also related to the creation of organizational reputation through social media.

In another research on school performance, (Harrison, Rouse, and Villiers, 2012) emphasize the importance of performance measurement as part of the efforts to fulfill the public sector organizations' general accountability requirements. The accountability covers data collection, measurement structure, relationships within that structure, the accuracy of content, and the reporting format.

In the context of state apparatus performance in Indonesia, research by (Hazmi et al., 2012) studies the effect of budget goal clarity and public accountability on government officials' managerial performance. One of the results concludes that public accountability and budget goal clarity have not been appropriately implemented; thus, the managerial performance of the state apparatus personnel is still low. In another research, (Adiwirya \& Sudana, 2015) explain that accountability and transparency simultaneously positively affect performance-based budgeting.

Based on the explanation, another hypothesis is formulated as follows:

$\boldsymbol{H}_{5}:$ Financial management accountability has a positive effect on the performance of HEIs.

This study focuses on the important role of IQAS on organizational performance, the case on HEIs. To create a more insightful explanation, it is also necessary to examine the foundation of leadership's commitment to financial management accountability. These important roles are examined to reveal their implications for the performance of private HEIs. The hypotheses developed in this study are based on the relevant literature and the results from some relevant previous research. This study is mainly based on agency theory. The agency relationship in private HEIs is reflected from the separation between the ownership and the management functions of private HEIs. In an HEI, the foundation board acts as the principal who represents the owner of the HEI.

In contrast, HEI management acts as the agent who is in charge of managing and being responsible for HEI's performance to the foundation board. The interaction process between the foundation board and HEI management may create potential agency conflicts. These conflicts occur because HEI management acts differently from what is expected by the foundation board. The present research model is illustrated in Figure 1.

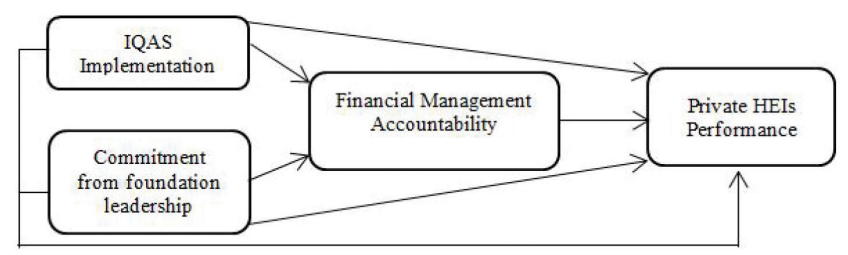

Figure 1: Research Model

\section{Research Methods and Materials}

The data were collected by distributing questionnaires to respondents, i.e., the top management of some private HEIs. The questionnaire was formulated using specific criteria that can be categorized into the IQAS implementation variable, the commitment from the foundation leadership, financial management accountability, and the Tridharma performance by HEIs. In the Indonesian context, Tridharma Perguruan Tinggi or the three pillars of higher education consist of education, research, and community service, which must be performed by each HEI.

This study's population was 480 private HEIs under Region IV of Service Institution for Higher Education in West Java and Banten. The sample size was calculated using the Slovin formula sampling technique with an error margin of $5 \%$, which resulted in an estimated sample size of 219 private HEIs. The collected data reached 108 respondents with a rate of return of $49.32 \%$. This figure agrees with (Mellahi \& Harris, 2016), who suggests that when the response rate for distributing questionnaires is between $35 \%$ and $50 \%$, it is considered sufficient for management research. In other words, the questionnaire results can be further processed to the data analysis stage.

The data were analyzed using multivariate statistics with two dependent variables (financial management accountability and performance of private HEIs) and two independent variables (implementation of IQAS and commitment from the foundation leadership). Furthermore, the results of the Structural Equation Modeling (SEM) method can provide an answer to the research problems.

\section{Results and Discussion}

\subsection{Results}

\subsubsection{Descriptive Statistics}

The data are grouped based on the score range and criteria to determine the respondents' average answers. The score range and criteria are presented in Table 1.

The results of the descriptive analysis of all research variables are presented in Table 2 . 
Table 1: Score Range and Criteria of Data

\begin{tabular}{|l|c|c|}
\hline No & Average Score & Criteria \\
\hline 1 & $1.00-1.80$ & Poor \\
\hline 2 & $1.81-2.61$ & Fair \\
\hline 3 & $2.62-3.42$ & Average \\
\hline 4 & $3.43-4.23$ & Good \\
\hline 5 & $4.24-5.00$ & Excellent \\
\hline
\end{tabular}

Table 2: Descriptive Analysis of Research Variables

\begin{tabular}{|l|l|c|c|c|c|c|c|}
\hline No & \multicolumn{1}{|c|}{ Variables } & Real Score & Max Score & Mean & $\begin{array}{c}\% \\
\text { Realisation }\end{array}$ & $\%$ GAP & Criteria \\
\hline 1 & Implementation of IQAS & 12.651 & 17.820 & 3,55 & 70,99 & 29,01 & Good \\
\hline 2 & $\begin{array}{l}\text { Commitment from Foundation } \\
\text { Leadership }\end{array}$ & 4.213 & 5.400 & 3,90 & 78,02 & 21,98 & Good \\
\hline 3 & $\begin{array}{l}\text { Accountability of Financial } \\
\text { Performance }\end{array}$ & 2.064 & 2.700 & 3,82 & 76,44 & 23,56 & Good \\
\hline 4 & Organizational Performance & 334 & - & 3,09 & & & \\
\hline
\end{tabular}

It can be seen from Table 2 that the variable measurement of the variant variables has shown promising results. This is indicated by the mean scores of the respondents' answers between 3.43 and 4.23 , which are considered acceptable

\subsubsection{Goodness-of-Fit (GoF)}

In Structural Equation Modeling (SEM), before testing the hypothesis, the model is measured by conducting a Confirmatory Factor Analysis (CFA) testing to test whether all observed variables have met construct validity and reliability elements. In other words, the observed variables should be ready to be used to measure the constructs. Furthermore, after testing the measurement model, the next step is to undergo structural model testing. The Goodnessof-Fit (GOF) values from the Confirmatory Factor Analysis (CFA) can be determined, as is shown in Table 3.

The data in Table 3 indicate that the model is considered a good fit. Therefore, it meets the requirements to proceed to the hypothesis testing stage.

\subsubsection{Hypothesis Testing}

The results of statistical tests on the structural model are represented by the following equations:

(1) $\mathrm{AKTB}=-0.020 * \mathrm{SPMI}+0.03 * \mathrm{KPY}$ where AKTB is financial management accountability, SPMI is IQAS, and KPY is commitment from foundation leadership.

$$
\text { (2) } \mathrm{KNJ}=0.088 * \mathrm{AKTB}+0.088 * \mathrm{SPMI}+0.043 * \mathrm{KPY}
$$

where KNJ is performance of private HEIs, SPMI is IQAS, and KPY is commitment from foundation leadership.

The results of the hypothesis testing are shown in Figure 2.

Based on Figure 2, the results of the hypothesis testing are presented in Table 4.

\subsection{Discussion}

\subsubsection{The Influence of the Implementation of SPMI/ IQAS on Financial Management Accountability}

The hypothesis testing results show that the implementation of IQAS has no significant effects on financial management accountability. This finding proves that the assessment instruments in IQAS are dominated by the assessment instruments of managerial aspects than those of financial aspects. This means that the financial management aspect gets the smallest portion of the Internal Quality Assurance System (or SPMI) instruments. These results confirm the research findings conducted by Sari et al. (2017), which show that internal audit does not affect accountability. 
Table 3: Goodness-of-Fit of Confirmatory Factor Analysis (CFA)

\begin{tabular}{|c|c|c|c|c|}
\hline No & $\begin{array}{l}\text { Goodness-of-Fit } \\
\text { Index }\end{array}$ & Parameter & Values & Conclusion \\
\hline \multicolumn{5}{|c|}{ Absolute } \\
\hline 1 & $x^{2}$ & $P$-value $\geq 0,05$ & $174.25(P=0.0)$ & Bad fit \\
\hline 2 & GFI & $\mathrm{GFI} \geq 0,90$ & 0,90 & Good fit \\
\hline 3 & SRMR & SRMR $<0.1$ & 0,064 & Good fit \\
\hline 4 & RMSEA & RMSEA $\leq 0,08$ & 0,10 & bad fit \\
\hline 5 & Normed $X^{2}\left(X^{2} / d f\right)$ & $\begin{array}{l}\text { Normed } X^{2}<2=\text { very good; } \\
2-5 \text { acceptable }\end{array}$ & $174 \cdot 25 / 41=4,25$ & Acceptable \\
\hline \multicolumn{5}{|c|}{ Incremental } \\
\hline 6 & TLI / NNFI & $\mathrm{NNFI} \geq 0,90$ & 0,93 & good fit \\
\hline 7 & $\mathrm{NFI}$ & $\mathrm{NFI} \geq 0,90$ & 0,93 & good fit \\
\hline 8 & $\mathrm{RFI} / \mathrm{RNI}$ & $\mathrm{RFI} \geq 0,90$ & 0,91 & good fit \\
\hline 9 & $\mathrm{IFI}$ & $\mathrm{IFI} \geq 0,90$ & 0,95 & good fit \\
\hline 10 & $\mathrm{CFI}$ & $\mathrm{CFI} \geq 0,90$ & 0,95 & good fit \\
\hline \multicolumn{5}{|c|}{ Parsimony } \\
\hline 11 & AGFI & $A G F I \geq 0,90$ & 0,84 & moderate fit \\
\hline
\end{tabular}

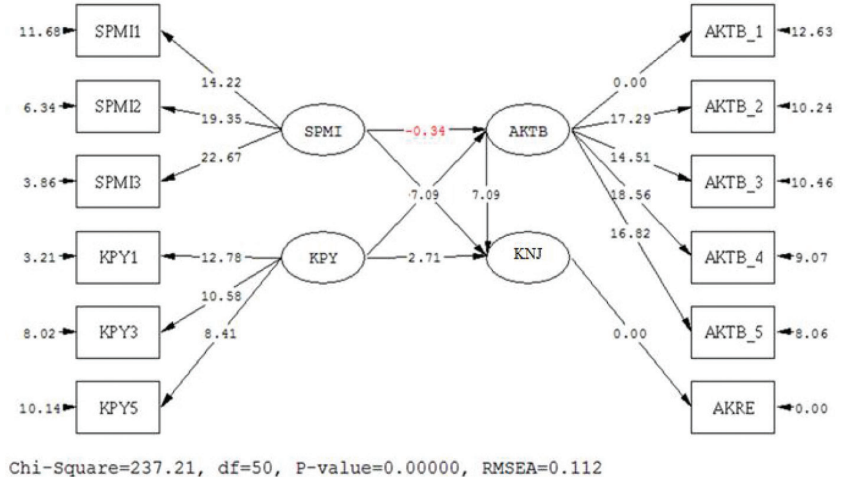

Figure 2: The Results of Hypothesis Testing

Table 4: The Results of Hypothesis Testing

\begin{tabular}{|l|l|c|c|c|c|c|}
\hline & & & $\begin{array}{c}\text { Direct } \\
\text { Effect }\end{array}$ & S.E. & t-Value & Hypotheses \\
\hline SPMI & $\rightarrow$ & AKTB & -0.02 & 0.06 & -0.34 & Rejected \\
\hline SPMI & $\rightarrow$ & KNJ & 0.09 & 0.01 & 7.09 & Accepted \\
\hline KPY & $\rightarrow$ & AKTB & 0.30 & 0.07 & 4.03 & Accepted \\
\hline KPY & $\rightarrow$ & KNJ & 0.04 & 0.02 & 2.71 & Accepted \\
\hline AKTB & $\rightarrow$ & KNJ & 0.09 & 0.01 & 7.09 & Accepted \\
\hline
\end{tabular}

\subsubsection{The Influence of the Implementation of SPMI on Organizational Performance}

The hypothesis testing results also show that the implementation of IQAS has a significant positive effect on HEIs' performance of Tridharma. This demonstrates that foundation leadership has the authority to make strategic decisions on the development of HEIs. One of the aspects decided by the foundation leadership is the budget approval for the operations and development of HEIs by considering the expected goal: to make HEIs earn the public trust. The high level of public interest in enrolling in a particular HEI can affect HEI's financial and non-financial yields. The full commitment from the foundation leadership is reflected in their support and monitoring for HEI's operations and development. Foundation leadership who can understand the management and development of HEIs are more likely to boost the performance of HEIs in a better direction. This present study confirms (Pradhan \& Pradhan, 2015) findings, which suggest that both transformational leadership and affective organizational commitment have a significant positive relationship on the performance of institutions.

\subsubsection{The Influence of Commitment from Foundation Leadership on Financial Management Accountability}

The hypothesis testing results show that the commitment from foundation leadership has a significant positive effect 
on financial management accountability. The findings confirm that HEIs' financial management accountability is the responsibility of HEIs' management. The foundation leadership's role is reflected in their approval of the operational and development budgets proposed by HEIs' management. Thus, hypothesis testing results indicate that the foundation leadership's commitment is positively reflected in HEIs' financial management accountability. These results are in line with the results of research by (Fettry, 2015) and (Agyemang et al. , 2017), which suggest that personnel commitments in organizations affect accountability.

\subsubsection{The Influence of Commitment from Foundation Leadership on HEIs' Performance of Tridharma}

The results of hypothesis testing also show that the commitment from foundation leadership has a significant positive effect on the performance of Tridharma by HEIs. These findings indicate that foundation leaders have the authority to make strategic decisions on higher education development. This demonstrates that foundation leaders have the authority to make strategic decisions on the development of HEIs. One of the aspects decided by the foundation leadership is the budget approval for the operations and development of HEIs by considering the expected goal: to make HEIs earn the public trust. The high level of public interest in enrolling in a particular HEI can affect HEI's financial and non-financial yields. The full commitment from the foundation leadership is reflected in their support and monitoring for HEI's operations and development. Foundation leadership who can understand the management and development of HEIs will boost the performance of HEIs in a better direction. This present study confirms (Pradhan \& Pradhan, 2015) findings, which suggest that transformational leadership and affective organizational commitment have a significant positive relationship on the performance of organizations.

\subsubsection{The Influence of Financial Management Accountability on HEIs' Performance of Tridharma}

The hypothesis testing results indicate that financial management accountability has a significant positive effect on HEI's performance of Tridharma. These findings also confirm that the financial management aspect is essential in the process of accreditation assessment of study programs and institutions conducted by the external quality assurance system, which is carried out by BAN-PT (National Accreditation Board for Higher Education) or other independent accreditation agencies (LAM). Financial management becomes essential because the entire activities of HEIs should end with financial reporting. Therefore, financial and non-financial aspects are two interrelated and complementary aspects of the accreditation process. This study confirms the findings of research conducted by (Harrison et al., 2012). They suggest that performance measurement is crucial as part of the efforts to meet organizations' general accountability requirements.

\section{Conclusions}

In general, this study's results conclude that implementing the internal quality assurance system (IQAS) does not affect financial management accountability. However, the implementation of IQAS has a positive effect on HEIs' performance of Tridharma. Furthermore, the commitment from foundation leadership has a significant positive effect on financial management accountability and HEIs' performance of Tridharma. Finally, financial management accountability has a significant positive effect on HEIs' performance of Tridharma.

This study has some limitations and suggestions. First, the data were obtained only from private HEIs under the Region IV of Service Institutions in West Java and Banten. Therefore, it would be much more significant if further research can use data from HEIs from all regions in Indonesia to yield better conclusions. Second, the study used two independent variables and two dependent variables. Future research should also add other variables from various factors to enhance the research results on this topic and expand it to other areas of research.

\section{References}

Adiwirya, M., \& Sudana, I. P. (2015). Accountability, transparency, and performance-based budgeting in Denpasar city regional work units. E-Jurnal Akuntansi, 11(2), 611-628.

Agyemang, G., O’Dwyer, B., Unerman, J., \& Awumbila., M. (2017). Seeking 'conversations for accountability': Mediating the impact of non-governmental organization (NGO) upward accountability processes. Accounting, Auditing and Accountability Journal, 30(5), 982-1007. https://doi: 10.1108/ AAAJ-02-2015-1969.

Akhtar, A., Durrani, A. B., \& Hassan, W. (2015). The impact of organizational commitment on job satisfaction and job performance: An empirical study from Pakistan. IOSR Journal of Business and Management, 17(6), 75-80.

Al-Thuneibat, A. A., Al-Rehaily, A. S., \& Basodan, Y. A. (2015). The impact of Internal Control Requirements on Profitability of Saudi Shareholding Companies. International Journal of Commerce and Management, 25(2), 196-217. https://doi: 10.1108/IJCOMA-04-2013-0033.

Altamuro, J., \& Beatty, A. (2010). How does internal control regulation affect financial reporting? Journal of Accounting 
and Economics, 49(1-2), 58-74. https://doi: 10.1016/j. jacceco.2009.07.002.

Aramide, S. F., \& Bashir, M. M. (2015). The effectiveness of internal control system and financial accountability at local government level in Nigeria. International Journal of Research in Business Management, 3(8), 1-6.

Aristanti, W. (2015). The influence of internal control system on the financial accountability of elementary schools in Bandung, Indonesia. Research Journal of Finance and Accounting, 6(24), 91-96.

Atmojo, M. (2012). The influence of transformational leadership on job satisfaction, organizational commitment, and employee performance. International Research Journal of Business Studies, 5(2), 113-128. https://doi: 10.21632/ irjbs.5.2.113-128.

Awdat, A. A. (2015). The impact of the internal audit function to improve the financial performance of commercial banks in Jordan Utautcaat. Citeseer, 6(3), 217-26.

Becker, K., \& Lee, J. W. (2019). Organizational usage of social media for corporate reputation management. Journal of Asian Finance, Economics and Business, 6(1), 231-240. https://doi: 10.13106/jafeb.2019.vol6.no1.231.

Bianchi, C. (2010). Improving performance and fostering accountability in the public sector through system dynamics modelling: From an 'external' to an 'internal' perspective. Systems Research and Behavioral Science, 27(4), 361-384. https://doi: 10.1002/sres.1038.

Chadwick, C., Super, J. F., \& Kwon, K. (2015). Resource orchestration in practice: CEO emphasis on SHRM, commitment-based HR systems, and firm performance. Strategic Management Journal, 36(3), 360-376. https://doi: 10.1002/smj.2217.

Fettry, S. (2015). The influence of business ethics commitment on financial reporting quality. International Journal of Applied Business and Economic Research, 13(6), 4243-4263.

Hanushek, E. A., \& Raymond, M. E. (2005). Does school accountability lead to improved student performance? Journal of Policy Analysis and Management, 24(2), 297-327. https:// doi: 10.1002/pam.20091.

Harrison, J. A., Rouse, P., \& Villiers, C. D. (2012). Accountability and performance measurement: A stakeholder perspective. Journal of CENTRUM Cathedra: The Business and Economics Research Journal, 5(2), 43-58. https://doi: 10.7835/jccberj-2012-0077.

Hazmi, Y., Imran, A., Zuarni, Y. I., \& Said, H. (2012). The effect of budget clarity and public accountability on the managerial performance of Lhokseumawe city governments. Device World Uni., 13(2), 1036-1037.

Jensen, M. C. (2000). Theory of the firm: Governance, residual claims and organizational forms preface and introduction. Boston, MA: Harvard University Press.

Johari, R. J., Alam, M. M., \& Said, J. (2018). Assessment of management commitment in Malaysian public sector.
Cogent Business and Management, 5(1). https://doi: $10.1080 / 23311975.2018 .1469955$

Kewo, C. L. (2017). The influence of internal control implementation and managerial performance on financial accountability local government in Indonesia. International Journal of Economics and Financial Issues, 7(1), 293-297.

Khan, R. A. G., Khan, F. A., \& Khan, M. A. (2011). Impact of training and development on organizational performance. Global Journal of Management and Business Research, 11, 62-68.

Lee, J. W. (2020a). Big data strategies for government, society and policy-Making. Journal of Asian Finance, Economics and Business, 7(7), 475-487. https://doi: 10.13106/jafeb.2020.vol7. no7.475.

Lee, J. W. (2020b). Green finance and sustainable development goals: The case of China. Journal of Asian Finance, Economics and Business, 7(7), 577-586. https://doi: 10.13106/jafeb.2020. vol7.no7.577.

Luthans, F. (2006). Organizational behavior indeks (10th ed). Yogyakarta, Indonesia: Andi

Mellahi, K., \& Harris, L. C. (2016). Response rates in business and management research: An overview of current practice and suggestions for future direction. British Journal of Management, 27, 426-437. https://doi: 10.1111/1467-8551.12154.

Pathak, J. (2005). Risk management, internal controls and organizational vulnerabilities. Managerial Auditing Journal, 20(6), 569-577. https://doi: 10.1108/02686900510606065.

Pradhan, S., \& Pradhan, R. K. (2015). An empirical investigation of relationship among transformational leadership, affective organizational commitment and contextual performance. Vision: The Journal of Business Perspective, 19(3), 227-235. https://doi: 10.1177/0972262915597089.

Setiawan, B., Afiff, A. Z., \& Heruwasto, I. (2020). Integrating the theory of planned behavior with norm activation in a pro-environmental context. Social Marketing Quarterly, 26(3), 244-258. https://doi.org/10.1177/1524500420949220

Setiawan, B., Panduwangi, M., \& Sumintono, B. (2018). A rasch analysis of the community's preference for different attributes of Islamic banks in Indonesia. International Journal of Social Economics, 45(12), 1647-166. https://doi: 10.1108/IJSE-072017-0294.

Tuan, N., \& Nguyen, D. (2019). A theoretical model studying the impact of internal control on performance and risks of Vietnam commercial banks. International Research Journal of Finance and Economics, 5(12), 0-13.

Wardiwiyono, S. (2012). Internal control system for Islamic micro financing: An exploratory study of baitul maal wat tamwil in the city of Yogyakarta Indonesia. International Journal of Islamic and Middle Eastern Finance and Management, 5(4). https://doi: 10.1108/17538391211282836.

Zurnali, C. (2010). Learning organization, competency, organizational commitment, and customer orientation: Knowledge Worker. Bandung, Indonesia: Unpad Press. 